\title{
As, Cu AND Zn CONCENTRATION IN SANITARY SEWAGE SLUDGE FERTILIZED SOIL AND IN CRAMBE AND CORN GRAINS
}

\author{
Paulo H. S. Cardoso ${ }^{1 *}$, Izabelle de P. Sousa ${ }^{2}$, Geraldo R. Zuba Junio ${ }^{3}$, Paula W. B. Gonçalves ${ }^{3}$, \\ Regynaldo A. Sampaio ${ }^{3}$
}

1*Corresponding author. Universidade de São Paulo/ Piracicaba - SP, Brasil. E-mail: paulohenrique.sc@ hotmail.com

\section{KEYWORDS}

biosolid, Crambe abyssinica, organic fertilization, Zea mays.

\begin{abstract}
This study aimed to evaluate the total contents of $\mathrm{As}, \mathrm{Cu}$ and $\mathrm{Zn}$ in the profile of a Haplic Cambisol cultivated with crambe and corn and fertilized with sanitary sewage sludge and to compare them with those obtained in other forms of fertilization, as well as the content of metals in the grain of these crops. Two experiments were carried out in the field, one with maize cultivation and another with crambe, both were delineated as randomized blocks with four treatments and six replicates, which were: without fertilization, fertilization with sewage sludge dewatered and dried in the sun, with dry sewage sludge and with mineral fertilizers. At the end of the experiments soil samples were collected at $15,50,100,150$ and $200 \mathrm{~cm}$ depth for analysis of the total contents of $\mathrm{As}, \mathrm{Cu}$ and $\mathrm{Zn}$, as well as the grain of the crops. No differences were observed among the treatments. The total contents of $\mathrm{As}, \mathrm{Cu}$ and $\mathrm{Zn}$ in the soil in both experiments and in the corn grains are below the limits of prevention and the maximum limit in grains established by the Brazilian resolutions. In relation to depth, the metal contents in the samples collected from the soil submitted to the fertilization treatments were similar to those quantified in the plots that did not received fertilization, but there was accumulation of $\mathrm{Cu}$ and $\mathrm{Zn}$ in the upper layers of the soil that received fertilization.
\end{abstract}

\section{INTRODUCTION}

The advancement of the crisis in water supply, caused by the scarcity of rain and its inadequate use, there is pressure from the society and especially from environmental agencies in the use of techniques that aim at the decontamination of rivers and the treatment of wastewater and sewage. However, this measure generates a by-product called sewage sludge, which, when incorrectly disposed, ends up negatively affecting the environment (Merlino et al., 2010).

A suitable and environmentally correct alternative is the application of sanitary sewage sludge in agricultural and forestry areas, as a soil conditioner and / or organic fertilizer, since it presents in its constitution macro and micronutrients, in addition high organic matter content (Dalpisol et al., 2017; Kummer et al., 2016). However, sewage sludge contains contaminants such as heavy metals, pathogenic organisms and persistent organic compounds. The metals commonly found in sewage sludge are arsenic (As), cadmium $(\mathrm{Cd})$, lead $(\mathrm{Pb})$, copper $(\mathrm{Cu})$, chromium $(\mathrm{Cr})$, nickel $(\mathrm{Ni})$ and zinc $(\mathrm{Zn})$ (Bettiol \& Camargo, 2006).

High levels of heavy metals in sanitary sewage sludge can give the soil high toxicity and make it unfeasible in agricultural, forestry and livestock production areas, which can be accumulated in plant tissues, thus entering the food chain and causing serious damage in animals and humans' health (Rehman et al., 2017).

Heavy metals can be found under five different soil forms, i.e. at different levels of solubility: (a) dissolved; (b) exchangeable; (c) bound to soil structures (specific adsorption); (d) insoluble (forming precipitates). The solubility of metals is dependent on several factors, both the metals and the environment in which they are found. These factors are the metal content, the type of connection they make to the soil, hydrogenionic potential $(\mathrm{pH})$, organic matter $(\mathrm{OM})$ and the cation exchange capacity (CEC) (Zeng et al., 2011).

\footnotetext{
${ }^{2}$ Universidade Federal de Viçosa/ Viçosa - MG, Brasil.

${ }^{3}$ Universidade Federal de Minas Gerais/ Montes Claros - MG, Brasil.

Received in: 12-14-2017

Accepted in: 4-11-2018
} 
Heavy metals, when in the exchangeable and dissolved forms, can leach into the soil profile, contaminating their lower layers and reaching the groundwater, contaminating groundwater and, subsequently, waterways.

Considering the pollutant potential of heavy metals, it is very important to study their behavior in the soil profile fertilized with sanitary sewage sludge. Thus, the objective of this study was to evaluate the total contents of $\mathrm{As}, \mathrm{Cu}$ and $\mathrm{Zn}$ in the profile of a Haplic Cambisol cultivated with crambe and corn and fertilized with sanitary sewage sludge and to compare them with those obtained in other forms of fertilization, as well as the metals' content in the grains of these crops.

\section{MATERIAL AND METHODS}

The experiments were conducted at the experimental farm of the Institute of Agricultural Sciences (ICA) of the Federal University of Minas Gerais (UFMG), Montes Claros campus, from December 2013 to March 2014 with total precipitation of $529.3 \mathrm{~mm}$, an average maximum temperature of $30.4{ }^{\circ} \mathrm{C}$ Minimum $20.3{ }^{\circ} \mathrm{C}$ and average relative humidity of $66.6 \%$ air (INMET, 2013). According to the Köppen classification, the predominant climate in the region is the Aw - tropical savannah, with rainy summer and dry winter. In the experimental areas, samples composed of Cambisol Haplic were collected in the $0-20 \mathrm{~cm}$ layer for chemical and physical routine characterization (Table 1) and heavy metal contents (Table 2).

TABLE 1. Chemical and physical attributes of the soil used in the experiment.

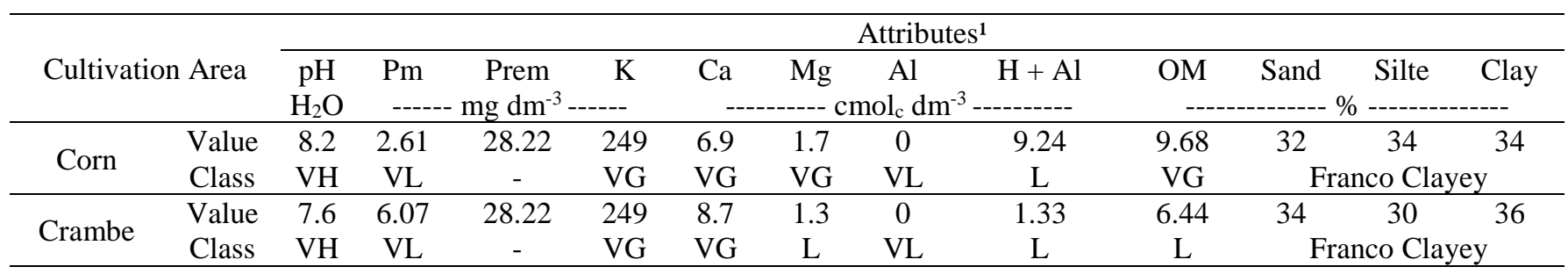

Pm -Mehlich Phosphor; Prem - Remaining Phosphorus; VH - Very high; VG - Very Good; L -Low; VL - Very Low.

${ }_{1}$ According to Embrapa methodologies (1997).

TABLE 2. Initial total content of heavy metals in the soil and sanitary sewage sludge used in the experiment.

\begin{tabular}{|c|c|c|c|}
\hline & \multicolumn{3}{|c|}{ Attributes } \\
\hline & As & $\begin{array}{c}\mathrm{Cu} \\
\mathrm{mg} \mathrm{kg}^{-1}\end{array}$ & $\mathrm{Zn}$ \\
\hline SSDDS & 0.14 & 158.00 & 862.20 \\
\hline DSS & 0.23 & 149.00 & 862.20 \\
\hline Crambe Soil & 0.26 & 13.3 & 38.13 \\
\hline Corn Soil & 0.27 & 11.6 & 30.90 \\
\hline
\end{tabular}

DSS - Dry Sewage Sludge; SSDDS - Sanitary sewage sludge dewatered and dried in the sun

The two types of sanitary sewage sludge used were obtained at the Montes Claros Sewage Treatment Plant (STP), operated by the Minas Gerais Sanitation Company (COPASA). At this station, there are reactors for Upflow Anaerobic Sludge Blanket (UASB). The liquid effluents from these reactors follow to aerobic biological filters. In the final stage of sewage treatment, the decantation process occurs, and the water can be released on the stream. The sanitary sewage sludge produced in the anaerobic reactors passes through the centrifugation and heat treatment processes at $350{ }^{\circ} \mathrm{C}$ for a period of 30 minutes.

In order to perform this work, the sewage sludge cake was used after its centrifugation and, afterwards, drying in the sun, on a canvas with a layer of $10 \mathrm{~cm}$ in height, with this sludge having a water content of about 54 dag $\mathrm{kg}^{-1}$ and dry sewage sludge, produced at the end of the heat treatment, with water content of approximately 6 dag $\mathrm{kg}^{-1}$. The heavy metals detected and quantified in the sewage sludge were $\mathrm{As}, \mathrm{Cu}$ and $\mathrm{Zn}$ and their total contents are presented in Table 2.

The experiments were performed in randomized blocks and consisted in the cultivation of crambe and corn in four treatments and six replications. The fertilization is established according to the nutritional demand of each crop, as shown below. In the cultivation of corn (Zea mays) the Dekalb 390 hybrid was used, with an early cycle (115 days), with high resistance to lodging and semi-hard grains, whose fertilization demand is $160 \mathrm{~kg} \mathrm{ha}^{-1}$ of $\mathrm{N}, 120$ $\mathrm{kg} \mathrm{ha}^{-1}$ of $\mathrm{P}_{2} \mathrm{O}_{5}$ and $90 \mathrm{~kg} \mathrm{ha}^{-1}$ of $\mathrm{K}_{2} \mathrm{O}$ (Alves et al., 1999). According to this demand and the $\mathrm{N}$ content available in the different types of sanitary sewage sludge, the doses were:

T1 - Control (without fertilization);

T2 - Fertilization with sanitary sewage sludge dewatered and dried in the sun (SSDDS) - content of $10.59 \mathrm{~kg} \mathrm{t}^{-1}$, dry basis, of available nitrogen, providing a dose of $15.11 \mathrm{t} \mathrm{ha}^{-1}$;

T3 - Fertilization with dried sewage sludge (DSS) content of $6.34 \mathrm{~kg} \mathrm{t}^{-1}$, dry basis, of available nitrogen, providing a dose of $25.25 \mathrm{t} \mathrm{ha}^{-1}$;

T4 - Fertilization with NPK - $45 \mathrm{~kg} \mathrm{ha}^{-1}$ of urea, $662.5 \mathrm{~kg} \mathrm{ha}^{-1}$ of single superphosphate and $156.25 \mathrm{~kg} \mathrm{ha}^{-1}$ of potassium chloride, applied in the furrow, and $125 \mathrm{~kg}$ $\mathrm{ha}^{-1}$ of ammonium sulphate and $250 \mathrm{~kg} \mathrm{ha}{ }^{-1}$ of urea, applied as a cover, half of the doses at 30 days of sowing and the other half at 45 days.

Although they present the same origin, the dry sanitary sewage sludge presented lower available $\mathrm{N}$ content, this is due to the loss of nitrogen during its drying at $350{ }^{\circ} \mathrm{C}$. 
Fertilization in the treatments in which the sewage sludge was applied to the soil was carried out in a single time in the planting furrows. The row spacing was $0.80 \mathrm{~m}$, with 5 seeds per linear meter. The size of each plot was 6.0 $\mathrm{x} 4.8 \mathrm{~m}$, and the grains were collected from the central $4 \mathrm{~m}$ of the rows, eliminating the peripheral rows, as a border.

The crambe (Crambe abysinica) presents a 90-day cycle and was fertilized with $20 \mathrm{~kg} \mathrm{ha}^{-1}$ of N, $40 \mathrm{~kg} \mathrm{ha}^{-1}$ of $\mathrm{P}_{2} \mathrm{O}_{5}$ and $20 \mathrm{~kg} \mathrm{ha}^{-1}$ of $\mathrm{K}_{2} \mathrm{O}$, with formulation adjusted based on the recommendations of Broch et al. (2010). According to the available $\mathrm{N}$ content, the following doses were used: without fertilization (T1); $1.89 \mathrm{t} \mathrm{ha}^{-1}$ of sanitary sewage sludge dewatered and dried in the sun (T2); $3.16 \mathrm{t}$ ha $^{-1}$ of dry sanitary sewage sludge (T3); and fertilization with NPK with $120 \mathrm{~kg} \mathrm{ha}^{-1}$ of urea, $600 \mathrm{~kg} \mathrm{ha}^{-1}$ of single superphosphate and $93.3 \mathrm{~kg} \mathrm{ha}^{-1}$ of potassium chloride, applied in the planting furrow (T4).

Fertilization in the crambe crop was done in a single time in the planting furrows. The row spacing was $0.30 \mathrm{~m}$, with 25 seeds per linear meter. Each plot had four rows of $2.5 \mathrm{~m}$ long and the useful plot was formed by the 20 central plants, and the borders have been discarded.

Due to the fact that the irrigation system was fixed, taking into account the total area of the experiment, it was not possible to establish specific irrigation management for both crops. Thus irrigation was carried out according to corn crop, being applied a total depth of $490 \mathrm{~mm}$ in the area with corn and $367 \mathrm{~mm}$ in the crambe planting area, due to the difference in the cultivation period of the crops.

At the end of their cycles, the corn grains were collected from the central plants of the plots (composite sample) and taken to the Laboratory for Analysis of Residues for Agricultural Utilization (LARAA-ICA / UFMG), where they were dried, macerated and submitted to nitric digestion in the Laboratory of Agrochemical Research (LPA-ICA / UFMG), according to the methodology USEPA-3051 (EPA, 1994) in a microwave oven, for later analysis of heavy metals in atomic absorption spectrophotometer. It was not possible to perform the analysis on the crambe grains due to the low development of the crop.
After harvesting, four simple soil samples were collected on the planting lines of the useful areas, composing a composite sample, at depths of 15, 50, 100, 150 and $200 \mathrm{~cm}$, with Dutch traces, and stored in a refrigerator. Subsequently, a portion of each sample was dried in a forced air circulation oven at $65^{\circ} \mathrm{C}$, macerated in a porcelain mortar, passed in $0.5 \mathrm{~mm}$ sieve and realizing digestion with 3: 1 royal water $\left(\mathrm{HCl}: \mathrm{HNO}_{3}\right)$ in a digestion block for $\mathrm{As}, \mathrm{Cu}$ and $\mathrm{Zn}$ readings in an atomic absorption spectrophotometer (Mcgrath \& Cunliffe, 1985). For $\mathrm{pH}$ analysis, $10 \mathrm{~g}$ of soil was weighed and $25 \mathrm{~mL}$ of distilled water was added. After stirring and $1 \mathrm{~h}$ rest, the $\mathrm{pH}$ was measured (EMBRAPA, 1997).

For the statistical analysis of the soil total metals content it was adopted the split plot scheme, and the types of fertilizers of the main plots and the depths the subplots. The experimental results were submitted to analysis of variance, Tukey's test at $5 \%$ of probability and regression with tests of the coefficients up to $10 \%$ of probability by ttest, using software $\mathrm{R}$ version 3.2.0.

\section{RESULTS AND DISCUSSION}

\section{Effect of fertilizations on soil pH}

There was a reduction in the soil $\mathrm{pH}$ in relation to its initial $\mathrm{pH}$ (Table 1), mainly in the soil cultivated with corn. At the depth of $15 \mathrm{~cm}$ in the soil cultivated with crambe there was a small increase in $\mathrm{pH}$ with fertilizations with sanitary sewage sludge and NPK in relation to the treatment without fertilization. On the other hand, in the soil cultivated with corn there was a greater reduction in $\mathrm{pH}$ values (Table 3). The reduction in $\mathrm{pH}$ of the soil cultivated with corn occurred due to the application of sanitary sewage sludge and chemical fertilizer made at its highest dose, aiming to meet the nutritional demand of $\mathrm{N}$ by the crop, resulting in greater availability of nitrogen to be nitrified. Since the corn cultivation may also have caused a reduction in the $\mathrm{pH}$ of the control soil by the release of exudates in relation to the initial $\mathrm{pH}$ of this soil (Table 1), which may not have occurred in crambe cultivation due to the low development of the crop. In depth, soil $\mathrm{pH}$ did not present an adjustment to mathematical models.

TABLE 3. Soil pH cultivated with crambe and corn in different treatments.

\begin{tabular}{|c|c|c|c|c|}
\hline \multicolumn{5}{|c|}{ Crambe } \\
\hline \multirow{2}{*}{ Depth (cm) } & \multicolumn{4}{|c|}{ Treatments } \\
\hline & WF & SSDDS & DSS & $\mathrm{CF}$ \\
\hline 15 & $7.11 \mathrm{~b}$ & $7.24 \mathrm{ab}$ & $7.36 \mathrm{a}$ & $7.24 \mathrm{ab}$ \\
\hline 50 & $6.58 \mathrm{~b}$ & $6.67 \mathrm{~b}$ & $7.06 \mathrm{a}$ & $6.92 \mathrm{a}$ \\
\hline 100 & $5.27 \mathrm{~b}$ & $5.34 \mathrm{~b}$ & $5.67 \mathrm{a}$ & $5.43 \mathrm{~b}$ \\
\hline 150 & $4.87 \mathrm{~b}$ & $5.24 \mathrm{a}$ & $5.25 \mathrm{a}$ & $5.17 \mathrm{a}$ \\
\hline \multirow[t]{2}{*}{200} & $5.26 \mathrm{c}$ & $6.03 \mathrm{a}$ & $5.58 \mathrm{~b}$ & $5.49 \mathrm{~b}$ \\
\hline & \multicolumn{4}{|c|}{ Corn } \\
\hline \multirow{2}{*}{ Depth (cm) } & \multicolumn{4}{|c|}{ Treatments } \\
\hline & WF & SSDDS & DSS & $\mathrm{CF}$ \\
\hline 15 & $7.14 \mathrm{a}$ & $6.75 \mathrm{~b}$ & $6.57 \mathrm{~b}$ & $6.53 \mathrm{~b}$ \\
\hline 50 & $6.05 \mathrm{~b}$ & $7.44 \mathrm{a}$ & $6.21 \mathrm{~b}$ & $5.58 \mathrm{c}$ \\
\hline 100 & $4.93 \mathrm{~b}$ & $5.41 \mathrm{a}$ & $5.34 \mathrm{a}$ & $5.16 \mathrm{ab}$ \\
\hline 150 & $4.99 \mathrm{a}$ & $4.68 \mathrm{~b}$ & $4.76 \mathrm{ab}$ & $4.82 \mathrm{ab}$ \\
\hline 200 & $6.00 \mathrm{a}$ & $5.63 \mathrm{~b}$ & $5.54 \mathrm{~b}$ & $5.67 \mathrm{~b}$ \\
\hline
\end{tabular}

WF - Without fertilization (control); SSDDS - Sewage sludge dewatered and dried in the sun; DSS - Dry Sewage Sludge; CF - Chemical fertilization. Means followed by the same letter, lowercase in horizontal, do not present significant differences between them, by Tukey test at $5 \%$ probability. 
Nitrogen fertilization provides soil acidification by nitrification of ammonium, with production of two protons $\left(\mathrm{H}^{+}\right)$for each $\mathrm{NH}_{4}^{+}$nitrified (Costa et al., 2008). The application of sanitary sewage sludge provides immobilization and nitrogen nitrification (Antoniadis et al., 2008), oxidation of sulfides (Souza et al., 2012) in the sludge and the formation of organic acids in the organic matter degradation process by microorganisms (Villanueva et al., 2012). These processes can still be accelerated when under tropical climate conditions, where there is more activity and microbial biomass in the soil (Antoniadis et al., 2008), being the condition in which the experiment was conducted, thus accelerating the process of organic matter decomposition of the sludge, and initially releasing organic acids and $\mathrm{H}^{+}$ions in the medium. However, as the sanitary sewage sludge mineralizes, the release of salts in the medium occurs, which can raise soil $\mathrm{pH}$ (Gondek et al., 2018).

Total content of $\mathrm{As}, \mathrm{Cu}$ and $\mathrm{Zn}$ in sanitary sewage sludge and soil cultivated with crambe and corn
The CONAMA Resolution No. 375 of 2006 provides that the maximum total content of $\mathrm{As}, \mathrm{Cu}$ and $\mathrm{Zn}$ in sanitary sewage sludge is $41 ; 1,500$ and $2,800 \mathrm{mg} \mathrm{kg}^{-1}$, respectively (Brasil, 2006), these limits much higher than those found in sanitary sewage sludge used in this study (Table 2). Nascimento et al. (2014) also found lower total contents of $\mathrm{Cd}, \mathrm{Cr}, \mathrm{Cu}, \mathrm{Ni}, \mathrm{Pb}$ and $\mathrm{Zn}$ in relation to the legislation for sanitary sewage sludge, under different stabilization processes, to be used in agricultural cultivation areas.

As there was no significant interaction between fertilization types and soil depth ( $p>0.05)$, the effect of fertilization types and depths on total $\mathrm{As}, \mathrm{Cu}$ and $\mathrm{Zn}$ levels in the soil was analyzed separately. In relation to the types of fertilization, a significant statistical difference was observed only in relation to the total content of As in the soil cultivated with crambe, and the control presented a total As content lower than that obtained in the other treatments (Table 4). This may have occurred due to the application of As by the fertilizers used.

TABLE 4. Total As, $\mathrm{Cu}$ and $\mathrm{Zn}$ contents in soil cultivated with crambe and corn in different treatments.

\begin{tabular}{|c|c|c|c|c|c|c|}
\hline \multirow{3}{*}{ Treatments } & \multicolumn{3}{|c|}{ Soil cultivated with crambe } & \multicolumn{3}{|c|}{ Soil cultivated with corn } \\
\hline & As & $\mathrm{Cu}$ & $\mathrm{Zn}$ & As & $\mathrm{Cu}$ & $\mathrm{Zn}$ \\
\hline & \multicolumn{6}{|c|}{ 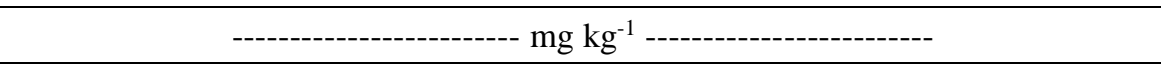 } \\
\hline $\mathrm{WF}$ & $0.69 \mathrm{a}$ & $14.62 \mathrm{a}$ & $61.67 \mathrm{a}$ & $0.78 \mathrm{a}$ & $17.78 \mathrm{a}$ & $29.63 \mathrm{a}$ \\
\hline SSDDS & $0.87 \mathrm{~b}$ & $15.25 \mathrm{a}$ & $59.10 \mathrm{a}$ & $0.79 \mathrm{a}$ & $19.69 \mathrm{a}$ & $37.46 \mathrm{a}$ \\
\hline DSS & $0.92 \mathrm{~b}$ & $14.72 \mathrm{a}$ & $73.40 \mathrm{a}$ & $0.81 \mathrm{a}$ & $19.80 \mathrm{a}$ & $36.94 \mathrm{a}$ \\
\hline $\mathrm{CF}$ & $0.90 \mathrm{~b}$ & $14.67 \mathrm{a}$ & $67.28 \mathrm{a}$ & $0.79 \mathrm{a}$ & $18.40 \mathrm{a}$ & $33.18 \mathrm{a}$ \\
\hline $\mathrm{CV}(\%)$ & 9.85 & 6.26 & 14.17 & 14.17 & 11.47 & 18.38 \\
\hline
\end{tabular}

WF - Without fertilization (control); SSDDS - Sewage sludge dewatered and dried in the sun; DSS - Dry Sewage Sludge; CF - Chemical fertilization.

Means followed by the same letter, lowercase in horizontal, do not present significant differences between them, by Tukey test at $5 \%$ probability.

The quality reference value (QRV) corresponds to the state of natural occurrence of an element / chemical substance in the soil and is defined by the environmental organs of each state (Brasil, 2009). In the State of Minas Gerais, the QRV for As is $8.0 \mathrm{mg} \mathrm{kg-1}$ (Minas Gerais, 2011), thus much higher than that found in soils of the experimental area, even those that were fertilized. The $\mathrm{Cu}$ and Zn QRVs are 49.0 and $46.5 \mathrm{mg} \mathrm{kg}^{-1}$ (Minas Gerais, 2011), respectively, so the total contents of $\mathrm{Cu}$ and $\mathrm{Zn}$ are considered to be naturally occurring, except only for $\mathrm{Zn}$ in soil cultivated with crambe, being above the established limit, including for the treatment without fertilization, and it is recommended the verification of QRVs. However, the total contents of $\mathrm{As}, \mathrm{Cu}$ and $\mathrm{Zn}$ in the soil are below the prevention value (PV) of $15 ; 60$ and $300 \mathrm{mg} \mathrm{kg}^{-1}$, respectively (Minas Gerais, 2011). The PV is characterized as the total limiting content of a particular element / chemical substance in the soil, without losing the capacity to sustain its main functions (Brasil, 2009).

Analyzing the total levels of $\mathrm{As}, \mathrm{Cu}$ and $\mathrm{Zn}$ in the soil profile, statistical significance was observed for soil cultivated with crambe and corn, thus adjusting regression models (Figure 1), showing trend along with the means of the treatment without fertilization (control), evidencing again the natural occurrence of these metals in the soil.

In the soil cultivated with crambe (Figure 1A), there was a quadratic response with a maximum total content of $0.94 \mathrm{mg} \mathrm{kg}^{-1}$ to $130 \mathrm{~cm}$ of depth, whereas in the soil cultivated with corn there was a cubic response, with a maximum content of $0.98 \mathrm{mg} \mathrm{kg}$ at $60 \mathrm{~cm}$ and a minimum of $0.63 \mathrm{mg} \mathrm{kg}^{-1}$ at $164 \mathrm{~cm}$ of depth. 


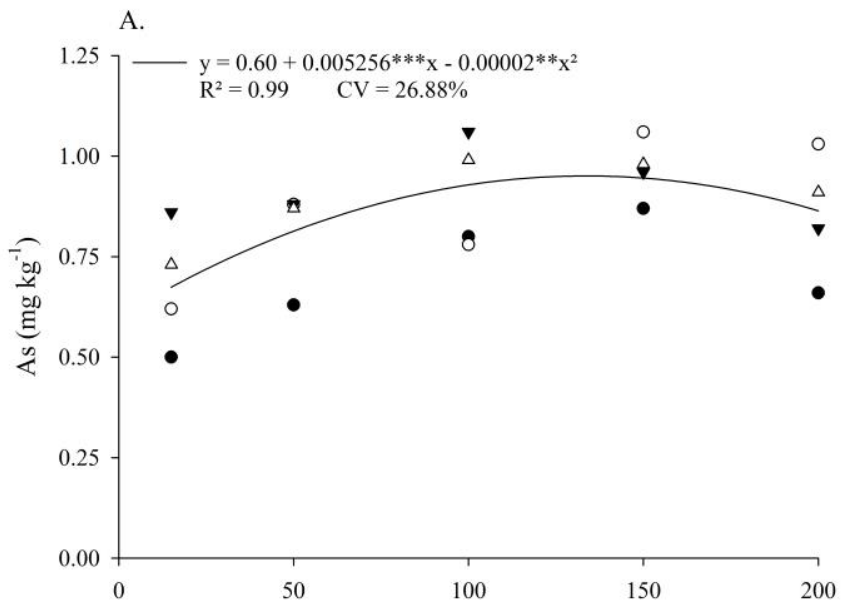

B.

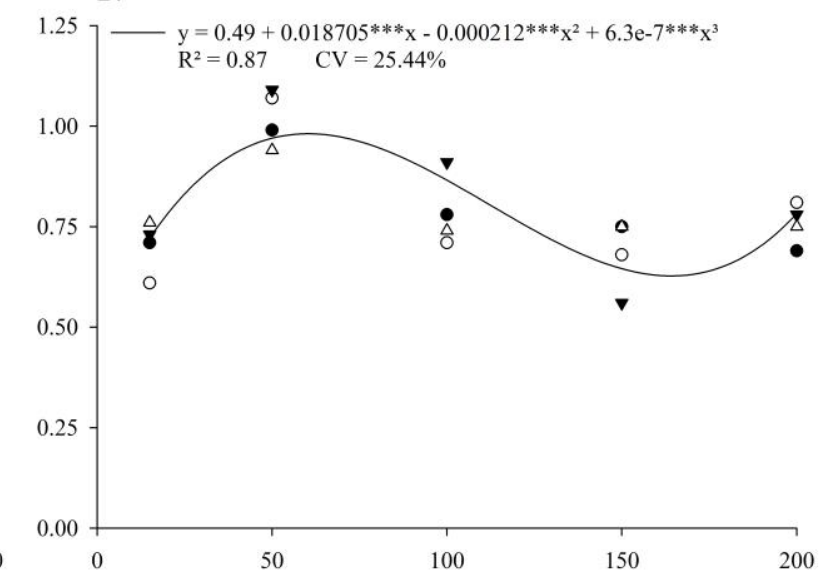

C.

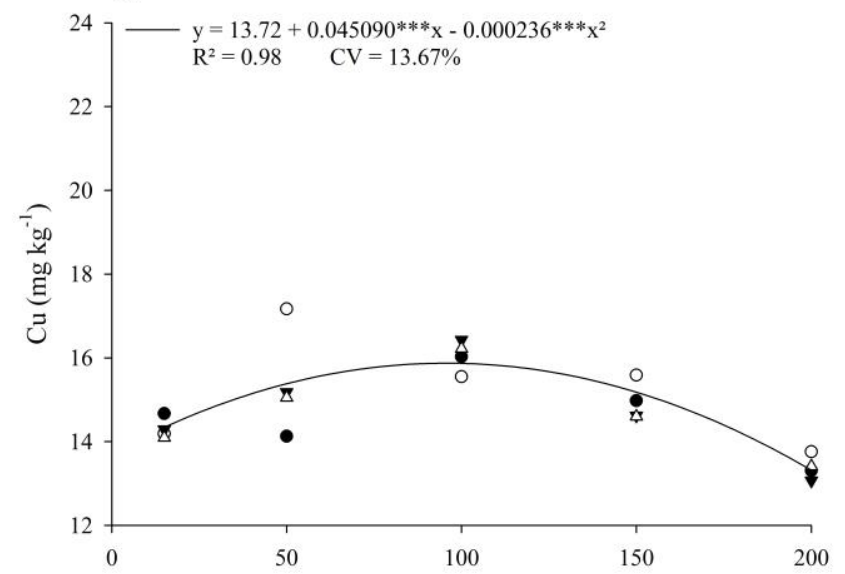

D.

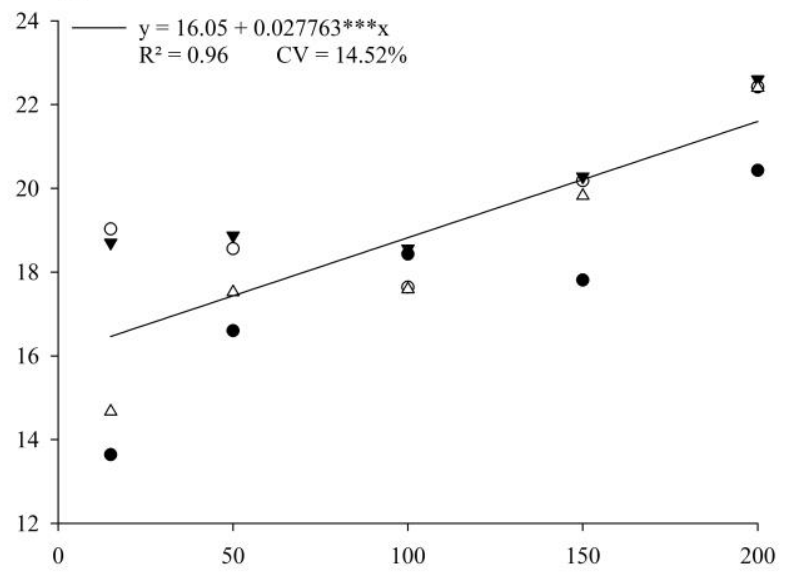

E.

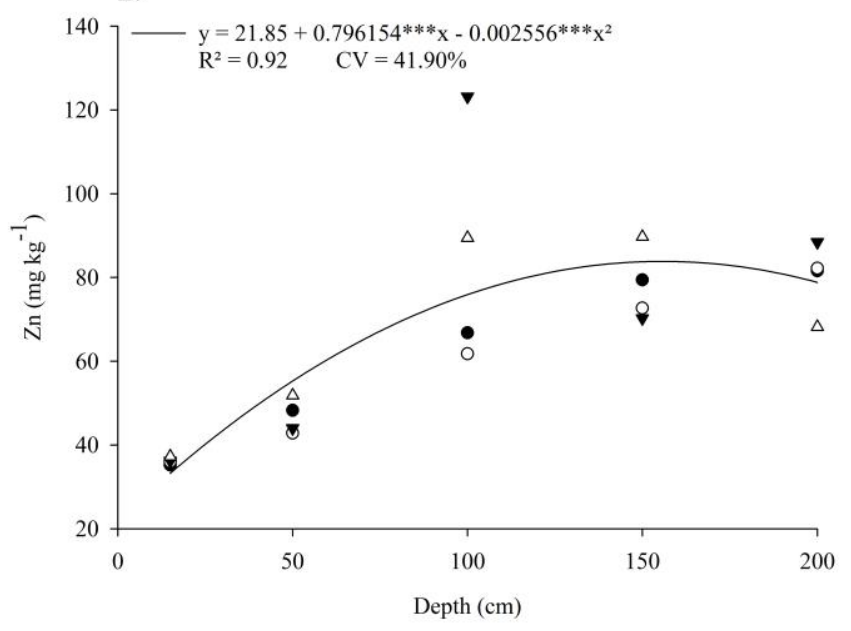

F.

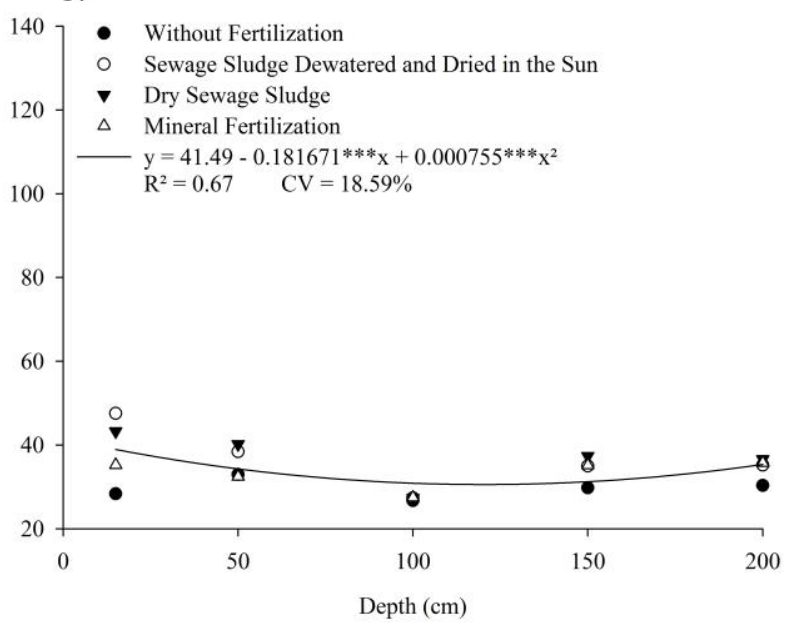

$* * *, * *$ - Significant by $\mathrm{T}$ test at 0.1 and $1 \%$ probability, respectively.

FIGURE 1. Behavior of the total content of $\mathrm{As}, \mathrm{Cu}$ and $\mathrm{Zn}$ on soil fertilized with sewage sludge in crambe (A, $\mathrm{C}$ and $\mathrm{E}$ ) and corn culture (B, D and F).

For the soil cultivated with crambe, there was a quadratic response in the total $\mathrm{Cu}$ content with a maximum of $15.87 \mathrm{mg} \mathrm{kg}^{-1}$ in depth of $96 \mathrm{~cm}$ (Figure 1C), whereas for the soil cultivated with corn, the response was linearly increasing (Figure 1D). It was also observed that the total content of $\mathrm{Cu}$ in the soil profile cultivated with corn was higher than that cultivated with crambe, this was due to the greater application of the fertilizers to meet the nutritional demand of $\mathrm{N}$ of the corn crop. As a consequence, it was also observed that there was an increase from 13.64 to 19.03 and $18.70 \mathrm{mg} \mathrm{kg}^{-1}$, an increase corresponding to 39.5 and $37.1 \%$ for SSDDS and DSS, respectively, in the total content of $\mathrm{Cu}$ at the depth of $15 \mathrm{~cm}$ and of 16.60 to 18.56 and $18.87 \mathrm{mg} \mathrm{kg}^{-1}$, increment corresponding to 13.6 and $11.8 \%$ for SSDDS and DSS, respectively, at depth of 50 $\mathrm{cm}$ in relation to the treatment without fertilization (Figure 1D).

The accumulation of $\mathrm{Cu}$ in the 15 and $50 \mathrm{~cm}$ layers of the soil is due to the strong connections with the clays and organic matter of the soil, resulting in lower leaching risks of the metal in the soil profile and, consequently, losses to the groundwater (Souza et al., 2012; Singh \& Kalamdhad, 2013). In addition, Oliveira et al. (2018), using dry sanitary sewage sludge from the same STP 
supplier of the residue used in this study, obtained, by sequential extraction, that $90.5 \%$ of $\mathrm{Cu}$ was found bound to stable fractions, such as carbonates, organic matter, sulphides and residual, whereas only $9.5 \%$ was in the soluble and exchangeable form.

The total $\mathrm{Zn}$ content obtained in the soil cultivated with crambe (Figure 1E) was higher than the soil cultivated with corn (Figure 1F), even with the greater application of sanitary sewage sludge and fertilizer in that soil. This may have occurred due to the low development of crambe plants, compromising the absorption of metals by the plant, maintaining its content at the end of the crop. On the other hand, the corn presented a good development, and then have absorbed the $\mathrm{Zn}$ and stored it in its organism, although the content of the metal in the aerial part and in the root of the plants has not been analyzed separately, so that can be confirmed. However, Oliveira et al. (2005) concluded that the content of heavy metals, including $\mathrm{Zn}$, is higher in the leaves than in the corn grains.

Regarding the $\mathrm{Zn}$ content in depth in the soil cultivated with corn, there was a quadratic response with a minimum content of $30.56 \mathrm{mg} \mathrm{kg} \mathrm{m}^{-1}$ at $120 \mathrm{~cm}$ depth, however, in the depth of $15 \mathrm{~cm}$ there was accumulation of $47.55 ; 43.25$ and $35.24 \mathrm{mg} \mathrm{kg}^{-1}$, increase corresponding to $67.7 ; 52.6$ and $24.3 \%$ of the total $\mathrm{Zn}$ content in the soil submitted to treatment with addition of SSDDS, DSS and $\mathrm{CF}$, respectively, in comparison with the non-fertilization, with a content of $28.34 \mathrm{mg} \mathrm{kg}^{-1}$. In the soil cultivated with crambe, a high accumulation of zinc was observed in its profile, with $83.85 \mathrm{mg} \mathrm{kg}^{-1}$ being accumulated at $155 \mathrm{~cm}$ depth, according to the adjusted model. In the treatment with dry sanitary sewage sludge, there was a higher accumulation, with a total content of $123.18 \mathrm{mg} \mathrm{kg}^{-1}$ at 100 $\mathrm{cm}$ depth, corresponding to approximately twice the content of $66.8 \mathrm{mg} \mathrm{kg}^{-1}$ observed in the treatment without fertilization at the same depth (Figure 1E).

Oliveira et al. (2018) studying the $\mathrm{Zn}$ speciation in dry sanitary sewage sludge, obtained that $4.9 \%$ of the $\mathrm{Zn}$ was in soluble and exchangeable form, justifying, in part, the metal leaching to a depth of $100 \mathrm{~cm}$.

In some studies, $\mathrm{Zn}$ is highly mobile in the soil profile and normally its mobility and / or adsorption is related to soil $\mathrm{pH}$ variations (Abat et al., 2012; Huang et al., 2014). These authors explain that in acidic soils there is an abundance of free $\mathrm{H}^{+}$ions, competing with the metals for the soil binding sites, reducing their adsorption. On the other hand, in alkaline soils there is attenuation of the competition, increasing the adsorption of the metals in the soil.

Huang et al. (2014) obtained an increasing linear response of $\mathrm{Cu}$ and $\mathrm{Zn}$ adsorption in soil with increasing values of $\mathrm{pH}$, proving that the higher the $\mathrm{pH}$ of the soil, the greater its adsorptive power. This explains the higher content of these elements in the upper layers of the soil, especially those cultivated with corn and fertilized with sanitary sewage sludge, where there was greater application of the fertilizer. However, Fang et al. (2016) report that with the increase of the dissolved organic matter in the soil, by the application of sanitary sewage sludge, significantly increased leaching of heavy metals in $\mathrm{pH}$ between 6 and 8. This would explain the $\mathrm{Zn}$ leaching at $100 \mathrm{~cm}$ depth in soil cultivated with crambe, because this soil had higher $\mathrm{pH}$ values (Table 3 ).
A possible solution to decrease the content of metals in depth is the use of crops, rotating or not, that have a deep root system, and can thus favor the cycling and / or export of the elements. In addition to recommending constant monitoring of the sanitary sewage sludge application areas, in order to verify if there is an increase in heavy metal levels in the soil and consequent environmental damage.

\section{Total content of $\mathrm{As}, \mathrm{Cu}$ and $\mathrm{Zn}$ in corn grains}

The crambe crop presented limited development, due to the rainfall intensity and the high relative humidity of the air in the period of the experiment implantation, which were 196.30 and $414.70 \mathrm{~mm}$ and 61.53 and $81.01 \%$ (INMET, 2013), respectively, for the months of November and December of 2013. The crambe crop does not tolerate rainy periods and high relative humidity, as stated by Falasca et al. (2010). Glaser (1996) also emphasizes that the high content of water in the soil can cause diseases such as alternaria (Alternaria brassicicola) and white mold (Sclerotinia sclerotiorum). Thus, there was no adequate development of the crambe plants, and it was not possible to quantify $\mathrm{As}, \mathrm{Cu}$ and $\mathrm{Zn}$ contents in the grains and in the rest of the biomass.

Table 5 shows the $\mathrm{Cu}$ and $\mathrm{Zn}$ content in the corn grains, and As was not detected in the grains. However, no significant statistical difference was found among the different treatments in relation to $\mathrm{Cu}$ and $\mathrm{Zn}$ contents. For the $\mathrm{Cu}$, there was a great variation among the repetitions, which caused in the increase of the $\mathrm{CV}$.

TABLE 5. $\mathrm{Cu}$ and $\mathrm{Zn}$ content of corn grains cultivated on soil fertilized with sanitary sewage sludge.

\begin{tabular}{lcc}
\hline Treatments & $\mathrm{Cu}$ & $\mathrm{Zn}$ \\
\hline WF & $------\mathrm{mg} \mathrm{kg}^{-1}-------$ \\
SSDDS & $10.15 \mathrm{a}$ & $37.80 \mathrm{a}$ \\
DSS & $9.72 \mathrm{a}$ & $40.39 \mathrm{a}$ \\
$\mathrm{CF}$ & $10.86 \mathrm{a}$ & $38.60 \mathrm{a}$ \\
$\mathrm{CV}(\%)$ & $11.29 \mathrm{a}$ & $41.04 \mathrm{a}$ \\
\hline
\end{tabular}

WF - Without fertilization (control); SSDDS - Sewage sludge dewatered and dried in the sun; DSS - Dry Sewage Sludge; CF Chemical fertilization.

Means followed by the same letter, lowercase in horizontal, do not present significant differences between them, by Tukey test at $5 \%$ probability.

Evaluating the effect of the sanitary landfill residue on the heavy metal content of corn, Prabpai et al. (2009) observed that there was a positive correlation between the soil metal content and the corn grains for $\mathrm{As}, \mathrm{Cd}, \mathrm{Cu}$ and $\mathrm{Zn}$, but not significant for $\mathrm{Cu}$ and $\mathrm{Zn}$. However, $\mathrm{Zn}$ was more likely to be accumulated in corn grains. However, Bai et al. (2017) found that the addition of sanitary sewage sludge in increasing doses $\left(0,30,75,150\right.$ and $\left.300 \mathrm{t} \mathrm{ha}^{-1}\right)$ had no influence on $\mathrm{Cu}$ content, but in the $\mathrm{Cd}$ and $\mathrm{Ni}$ contents and that there was increase for $\mathrm{Cr}, \mathrm{Zn}$ and $\mathrm{Mn}$ only in the higher doses in the corn grains, however, no metal exceeded the food limits, as observed in this study.

The Decree No. 55.871 of 1965 (ANVISA, 1965) establishes the maximum tolerance limits (MTL) of 30 and $50 \mathrm{mg} \mathrm{kg}-1$ of $\mathrm{Cu}$ and $\mathrm{Zn}$, respectively, in dry matter of food. Based on this decree, the $\mathrm{Zn}$ and $\mathrm{Cu}$ contents in the corn grains are below the maximum tolerance limits. 
Nogueira et al. (2008) studying the heavy metals content in soil and corn plants after nine years of annual application of increasing doses of sanitary sewage sludge $(45,90$ and $127.5 \mathrm{t} \mathrm{ha}^{-1}$ ), they found results similar to those of the present study, wherein the $\mathrm{Zn}$ content in the corn grain was below the ANVISA (1965) maximum tolerance limits.

According to Kabata-Pendias (2011), the metals' absorption by the plants varies with the type of the element, being the $\mathrm{Cu}$ and $\mathrm{Zn}$ actively absorbed by the roots and in a similar way, consequently, the behavior of these metals are antagonistic by competitively inhibiting the absorption of the other. The author also points out that the roots and their association with soil microorganisms are able to produce organic substances efficient in the release of heavy metals adsorbed on the soil particles, potentializing their absorption.

It is noteworthy that $\mathrm{Cu}$ and $\mathrm{Zn}$ are also micronutrients that are part of a series of plant metabolic processes. Thus, the high incorporation of these to the soil by the continuous application of sanitary sewage sludge must be controlled, as it may present risk to the plant due to high absorption and, consequently, nutritional imbalance and, later, phytotoxic effects.

\section{CONCLUSIONS}

The total contents of $\mathrm{As}, \mathrm{Cu}$ and $\mathrm{Zn}$ were similar in the treatments in which the soil was only receiving the chemical fertilization and in those in which sanitary sewage sludge was applied, having accumulation of $\mathrm{Cu}$ and $\mathrm{Zn}$ in the upper layers of the soil that received both chemical fertilization as sanitary sewage sludge.

The total $\mathrm{Cu}$ and $\mathrm{Zn}$ contents in corn grains were not influenced by the application of up to $25 \mathrm{t} \mathrm{ha}^{-1}$ of sanitary sewage sludge and remained below the maximum limit allowed by current legislation.

The disposal of sanitary sewage sludge in agriculture, especially as regards grain production, it may be adequate and a sustainable measure when considering the issue of accumulation in the soil and contamination of the product with heavy metals in application done in a single period of the culture.

\section{ACKNOWLEDGEMENTS}

We would like to thank the UFMG, Fapemig and CAPES, for the financial support to the project and grant of the scholarship and to COPASA for the donation of sanitary sewage sludge.

\section{REFERENCES}

Abat M, Mclaughlin MJ, Kirby JK, Stacey SP (2012) Adsortion and desortion of copper and zinc in tropical peat soils of Sarawak, Malaysia. Geoderma 175-176:58-63. DOI: https://doi.org/10.1016/j.geoderma.2012.01.024

Alves VMC, Vasconcellos CA, Freire FM, Pitta GVE, França GE, Rodrigues Filho A, Araújo JM, Vieira JR, Loureiro JE (1999) Milho. In: Ribeiro AC, Guimarães PTG, Alvarez V. HV. Recomendações para o uso de corretivos e fertilizantes em Minas Gerais: $5^{\mathrm{a}}$ aproximação. Viçosa, Comissão de Fertilidade do Solo do Estado de Minas Gerais, p314-316.
Antoniadis V, Robinson JS, Alloway BJ (2008) Effects of short-term $\mathrm{pH}$ fluctuations on cadmium, nickel, lead and zinc availability to ryegrass in a sewage sludge-amended field. Chemosphere 71(4):759-764. DOI: https://doi.org/10.1016/j.chemosphere.2007.10.015

ANVISA - Agência Nacional de Vigilância Sanitária (1965) Decreto n.55871. Normas reguladoras do emprego de aditivos para alimentos. Available in:

http://portal.anvisa.gov.br/wps/wcm/connect/414d2480474 58a7d93f3d73fbc4c6735/DECRETO+N\%C2\%BA+55.871 ,+DE+26+DE+MAR\%C3\%87O+DE+1965.pdf?MOD=AJ PERES. Accessed: Jun 01, 2015.

Bai Y, Zang C, Gu M, Gu C, Shao H, Guan Y, Zhou X, Shan Y, Feng K (2017) Sewage sludge as an initial fertility driver for rapid improvement of mudflat salt-soils. Science of the Total Environment 578(1):47-55. DOI: https://doi.org/10.1016/j.scitotenv.2016.06.083

Bettiol W, Camargo OA (2006) A disposição de lodo de esgoto em solo agrícola. In: Bettiol W, Camargo OA, Lodo de Esgoto: Impactos Ambientais na Agricultura. Jaguariuna, Embrapa Meio Ambiente, 349p.

Brasil. Ministério do Meio Ambiente (2006) Conselho Nacional de Meio Ambiente. Resolução n.375 Available in:

http://www.fundagresorg.br/biossolido/images/downloads/ res_conama37506. Accessed: Apr 20, 2015.

Brasil. Ministério do Meio Ambiente (2009) Conselho Nacional de Meio Ambiente. Resolução n.420. Available in:

http://www.mma.gov.br/port/conama/legiabre.cfm?codlegi $=620$. Accessed: Jul 07, 2015.

Broch DL, Ranno SK, Roscoe R (2010) Efeito de adubações de plantio e cobertura sobre a produtividade de crambe cv. fms brilhante após soja e milho. In: Congresso Brasileiro de Mamona; Simpósio Internacional de Oleaginosas e Energéticas. João Pessoa. Inclusão Social e Energia: Anais... Campina grande, Embrapa Algodão, p.652-657.

Costa KAP, Faquin V, Oliveira IP, Rodrigues C, Severino EC (2008) Doses e fontes de nitrogênio em pastagem de capim-marandu. I - Alterações nas características químicas do solo. Revista Brasileira de Ciência do Solo 32(4):15911599. DOI: http://dx.doi.org/10.1590/S010006832008000400023

Dalpisol M, Serrat BM, Motta ACV, Poggere GC, Bittencourt S, Barbosa JZ (2017) Zinc, copper and manganese availability in soils treated with alkaline sewage sludge from Paraná state (Brazil). Revista Ciência e Agrotecnologia 41(1):85-97. DOI: http://dx.doi.org/10.1590/1413-70542017411036916

EMBRAPA - Empresa Brasileira de Pesquisa Agropecuária (1997) Manual de métodos de análise de solo. Rio de Janeiro, Centro Nacional de Pesquisa de Solos, 2 ed. 212p.

EPA - Environmental Protection Agency (1994) Microwave assisted acid digestion of sediments, sludges, soils, and oils. Method 3051. EPA, 14p. Available in: http://cem.com/media/contenttype/media/literature/516_M etNote_DiscSPD_EPA_3051.pdf. Accessed: Sep 14, 2016. 
Falasca SL, Flores N, Lamas MC, Carballo SM, Anschau A (2010) Crambe abyssinica: an almost unknown crop with a promissory future to produce biodiesel in Argentina. International Journal of Hydrogen Energy 35(11):5808-5812. DOI: https://doi.org/10.1016/j.ijhydene.2010.02.095

Fang W, Wei Y, Liu J (2016) Comparative characterization of sewage sludge compost and soil: Heavy metal leaching characteristics. Journal of Hazardous Materials 310:1-10. DOI:

https://doi.org/10.1016/j.jhazmat.2016.02.025

Glaser LK (1996) Crambe: an economic assessment feasibility of providing multiple-peril crop insurance. Federal Crop Insurance Corporation. Available in: http://www.rma.usda.gov/pilots/feasible/pdf/crambe.pdf. Accessed: Jun 02, 2015.

Gondek K, Mierzwa-Hersztek M, Kopéc M (2018) Mobility of heavy metals in sandy soil after application of composts produced from maize straw, sewage sludge and biochar. Journal of Environmental Management 210:8795. DOI: https://doi.org/10.1016/j.jenvman.2018.01.023

Huang B, Li Z, Huang J, Guo L, Nie X, Wang Y, Zhang Y, Zeng G (2014) Adsorption characteristics of $\mathrm{Cu}$ and $\mathrm{Zn}$ onto various size fractions of aggregates from red paddy soil. Journal of Hazardous Materials 264:176-183. DOI: https://doi.org/10.1016/j.jhazmat.2013.10.074

INMET - Instituto Nacional de Meteorologia. Dados meteorológicos do município de Montes Claros/MG, nov./dez. 2013. Available in: http://www.inmet.gov.br/. Accessed: Jun 10, 2015.

Kabata-Pendias A (2011) Trace elements in soils and plants. New York City, CRC Press, 4 ed. 534p. Available in:

http://www.petronet.ir/documents/10180/2323242/Trace_ Elements_in_Soils_and_Plants. Accessed: Jun 10, 2015.

Kummer ACB, Grassi Filho H, Lobo TF, Lima RAS (2016) Composted sewage sludge in replacement of mineral fertilization on wheat production and development. Revista Engenharia Agrícola 36(4):706-714. DOI: http://dx.doi.org/10.1590/1809-4430-

Eng.Agric.v36n4p706-714/2016

McGrath SP, Cunliffe CH (1985) A simplified method for the extraction of the metals in sewage sludge on soils, microorganisms and plants. Journal of Industrial Microbiology \& Biotechnology 14:94-104.

Merlino LCS, Melo WJ, Macedo FG, Guedes ACTP, Ribeiro MH, Melo VP, Melo GMP (2010) Bário, cádmio, cromo e chumbo em plantas de milho e em latossolo após onze aplicações anuais de lodo de esgoto. Revista Brasileira de Ciência do Solo 34(6):2031-2039. DOI: http://dx.doi.org/10.1590/S0100-06832010000600027

Minas Gerais. Conselho Estadual de Política Ambiental (2011) Deliberação Normativa $\mathrm{N}^{\circ} 166$. Available in: http://www.siam.mg.gov.br/sla/download.pdf?idNorma=1 8414. Accessed: Sep 23, 2017.
Nascimento AL, Sampaio RA, Cruz SF, Zuba Junio GR, Barbosa CF, Fernandes LA (2014) Metais pesados em girassol adubado com lodo de esgoto submetido a diferentes processos de estabilização. Revista Brasileira de Engenharia Agrícola e Ambiental 18(7):694-699. DOI: http://dx.doi.org/10.1590/S1415-43662014000700004

Nogueira TAR, Oliveira LR, Melo WJ, Fonseca IM, Melo GMP, Melo VP, Marques MO (2008) Cádmio, cromo, chumbo e zinco em plantas de milho e em latossolo após nove aplicações anuais de lodo de esgoto. Revista Brasileira de Ciência do Solo 32(5):2195-2207. DOI: http://dx.doi.org/10.1590/S0100-06832008000500040

Oliveira ESA, Cardoso PHS, Sousa IP, Alvarenga AC, Rodrigues MN, Sampaio RA (2018) Copper and zinc fractionation in biosolid cultivated with Pennisetum purpureum in different periods. Revista Brasileira de Engenharia Agrícola e Ambiental 22(1):3-9. DOI: http://dx.doi.org/10.1590/1807-1929/agriambi.v22n1p3-9

Oliveira KW, Melo WJ, Pereira GT, Melo VP, Melo GMP (2005) Heavy metals in oxisols amended with biosolids and cropped with maize in a long-term experiment. Scientia Agricola 62(4):381-388. DOI: http://dx.doi.org/10.1590/S0103-90162005000400012

Prabpai S, Charerntanyarak L, Siri B, Moore MR, Noller BN (2009) Effects of residues from municipal solid waste landfill on corn yield and heavy metal content. Waste Management 29(8):2316-2320. DOI: http://dx.doi.org/10.1016/j.wasman.2009.02.009

Rehman ZU, Khan S, Brusseau ML, Shah MT (2017) Lead and cadmium contamination and exposure risk assessment via consumption of vegetables grown in agricultural soils of five-selected regions of Pakistan. Chemosphere 168:1589-1596. DOI: http://dx.doi.org/10.1016/j.chemosphere.2016.11.152

Singh J, Kalamdhad AS (2013) Assessment of bioavailability and leachability of heavy metals during rotary drum composting of green waste (Water hyacinth). Ecological Engineering 52:59-69. DOI: https://doi.org/10.1016/j.ecoleng.2012.12.090

Souza RAS, Bissani CA, Tedesco MJ, Fontoura RC (2012) Extração sequencial de zinco e cobre em solos tratados com lodo de esgoto composto de lixo. Química Nova 35(2):308-314. DOI: http://dx.doi.org/10.1590/S010040422012000200014 .

Villanueva FCA, Boaretto AE, Firme LP, Muraoka T, Nascimento Filho VF, Abreu Junior CH (2012) Mudanças químicas e fitodisponibilidade de zinco estimada por método isotópico, em solo tratado com lodo de esgoto. Química Nova 35(7):1348-1354. DOI: http://dx.doi.org/10.1590/S0100-40422012000700012

Zeng F, Ali S, Zhang H, Ouyang Y, Qiu B, Wu F, Zhang $\mathrm{G}$ (2011) The influence of $\mathrm{pH}$ and organic matter content in paddy soil on heavy metal availability and their uptake by rice plants. Environmental Pollution 159(1):84-91. DOI: https://doi.org/10.1016/j.envpol.2010.09.019 